solution of the problem of smoke pollution. Yet this problem in industrial and sanitary reconstruction will have to be faced when peace comes, and for that reason it seems unfortunate that the Local Government Board Committee on Smoke Abatement should have indefinitely postponed its meetings on the outbreak of war. J. B. C.

\section{METEOROLOGICAL PERSISTENCE.}

THERE is a special sense of appropriateness about the brochure entitled "Konstant auftretende secundäre Maxima und Minima im dem Jährlichen Verlauf der meteorologischen Erscheinungen," by Dr. Eli Van Rijckevorsel, published as No. 102 of the "Mededeelingen en Verhandelingen" of the Royal Meteorological Institute of the Netherlands. For the last dozen years the author has appeared to confine his published scientific activity to the subject of the persistence of secondary maxima and minima in annual meteorological phenomena, and this is his eleventh contribution on the same thesis, the last three of which have received the support of his national institute.

A detailed comparison of the whole series of "tracts" would be necessary to enable us to dogmatise as to the validity of the author's conclusions and the justification of his persistence. There is no doubt, however, that even this eleventh article taken by itself is full of interesting points. A long series of seventy-two years' barometric data from Christiania is dealt with in two thirty-six-year portions, and also as to twentyfive years allocated to sun-spot maxima and twentyfive years to minima in the same period. From the sun-spot point of view, a similar process is applied to shorter periods from Nertchinsk and Innsbruck. The main part of the data, however, consists of daily sums from thirty-three stations in the N. Hemisphere for periods ranging from forty-three years at Haparanda to four at Honolulu and St. Vincent (Cape Verde). The stations are well distributed, five with a mean latitude of $67^{\circ}$ and a range in longitude of nearly $100^{\circ}$; eight with mean latitude $5^{\circ}$, and with gaps in longitude of $120^{\circ}$ for the Pacific and $90^{\circ}$ for the Atlantic; nine with mean latitude $42^{\circ}$, and again a gap of $120^{\circ}$ in longitude for the Pacific; and eleven with mean latitude $2 \mathrm{I}^{\circ}$ in which the Pacific gap is partly bridged by Honolulu. Some of the tables appear to have had a decimal point omitted throughout, and the Honolulu table differs considerably from the others, but the principle of printing sums instead of means, when the periods vary considerably, seems to demand more explanation than the author has given, though this practice has probably been adopted and discussed in one of the ten earlier contributions which are not for the moment at hand.

An excellent series of plates shows the author's idea of the variation with latitude and longitude of the secondary oscillations with which he is dealing, and there is also a comparison of the resulting oscillations from a fifty winters' comparison of Greenwich barometer and thermometer, showing a mean lag of half a week from the barometric maximum to the temperature minimum; a similar comparison in diagrammatic form is given for Bucharest from a fifteen-year period.

Altogether there would appear to be thirty-five oscillations in the year superposed on the ordinary single solar oscillation, but having regard to the classic case of the three "icemen," now so generally discredited in this country, it may be some time before Dr. Rijckevorsel obtains much enthusiastic support among us, for though the reality of the alternations of weather is undeniable, our proverbial traditions nearly all postulate, not the same, but different conditions on a fixed date.

NO. 2508 , VOL. IOO]
THE SHORTAGE OF THE SUPPLY OF NON-PHOSPHORIC IRON ORE. ${ }^{1}$

A LREADY in the pre-war years the supplies of high-class hæmatite to the iron-smelting districts of Europe trom the nearer sources were getting short, and the time was in sight when, for iron ores low in phosphorus such as are required for the production of the "hæmatice grade" of pigiron demanded by those. who make steel by the "acid" process, we shall have either to turn our attention to sources of supply which are less readily accessible, or so to improve metallurgical processes that, from ores which are abundant in closer proximity to the coalnelds, trustworthy substitutes for "Bessemer-grade" acid steels can be economically produced. The thesis advanced by the author of these Howard lectures is that, notwithstanding that the low-grade phosphoric ores of the Englisn Jurassic rocks yield a pig-iron which for steel-making requires refining upon a basic hearth, in Britain the second of the two alternatives mentioned should be chosen.

The subject-matter dealt with in the lectures was assembled under two neads. In the first of the lectures the author presented a conspectus of-the various ironfields where ore production is in progress within the British Isles. In the second he passed in review the various orefields in foreign countries which, under peace conditions, sent produce, either raw or semimanufactured, from their iron mines to supply the British market.

Within the British area there is a remarkable absence of any considerable concentration of iron ore among geological formations of pre-Carboniferous age. The non-phosphoric hæmatites of the Carboniferous Limestone district occur as veins and impregnations, and extend some little distance downwards among these older rocks, but in their distribution they are limited to a narrow belt of country which ranges north and south through the English Lake District and the Forest of Dean, and are probably of post-Carboniferous date. They are less regular in their distribution, and therefore more expensive to exploit, than are the bedded ores associated with the Coal Measures or interstratified in thicker masses among the Jurassic rocks, and the shortage of home supplies of hæmatite has already long been felt.

In former days clay-band and black-band ores, interstratified among the Coal Measures, afforded the main supply of English and Scottish iron, but when steel superseded wrought-iron as the ordinary material for constructional engineering, economic conditions brought about the diminution of iron production from these ores, and though there lie in reserve more than thirty thousand million tons of such ore among our Coal Measures, that source of supply does not at present represent to our ironmasters a national asset which has any great marketable value.

Along the outcrop of the English Jurassic rocks between the coast of Dorset and the Cleveland Hills there is nowhere any lack of low-grade iron ore. In the neighbourhood of the Humber it is the Lower Lias which carries the ore-bed, but generally the Middle Lias is the more prolific horizon. In Northamptonshire the great development of iron ore is in the basal member of the Inferior Oolite series, and at Westbury, in Wiltshire, and throughout the southern counties, the most important development is in association with Corallian rocks. "Just as the Carboniferous is the great repository of Great Britain's fuel wealth, so the Turassic is the bank which holds our fluid reserves of iron ore. The gilt-edged securities of Cumbrian hæmatite are sound, but not unlimited in amount;

1 Abstract of the Howard Lectures delivered before the Royal Society of Arts on April 30 and May 7 hy Prof. W. G. Fearnsides, Sorby Professor of
Geology in the University of Sheffield. 
while the market for the vast quantities of the clayband and black-band ores of the Coal Measures must needs be written off. Our engineers prefer the produce of the hæmatite, but there is a shortage, and the price is therefore high. There is plenty of the lowgrade phosphoric ore available and cheap. Surely it is not beyond the skill of our metallurgists to make use of it, and obtain from it a product which, on its merits, will overcome the prejudice of the British engineers. This is the only domestic solution of the problem of the home shortage of non-phosphoric iron ore."

Probably it has been realised by few that the total quantity of metallic iron obtained from iron ore

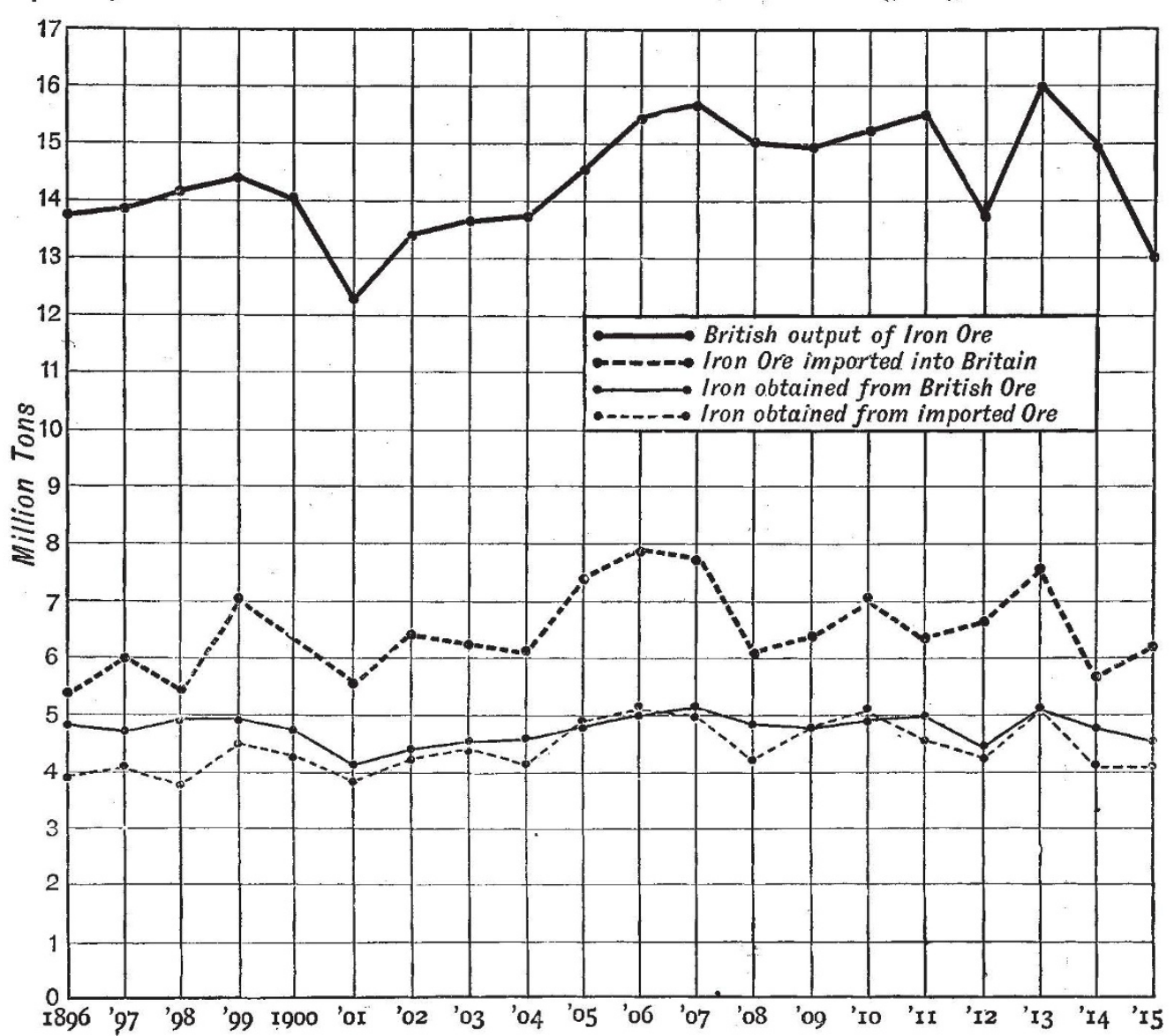

FIG. I.-Curve showing British output of iron ore and iron obtained from Briti.h and imported ore. pig-iron was fifteen million pounds, an advantage in favour of the foreign ore of 2.5 million pounds. The cost of the British ore at mine was 4.5 million pounds, and that of the foreign ore delivered at British ports seven million pounds, between which figures there is also a difference of 2.5 million pounds, so that the difference in cost of manufactured pig-iron made from home and from foreign ore is inconsiderable.

In the pre-war years the demand for hæmatite among the ironmasters of the Rhineland was, as in Britain, on the increase, and in consequence the centre of gravity of the hæmatite supply showed signs of a gradual shifting southwards and eastwards. In the future, rising demand and heavier freights, due to increasing length of rail and sea passage, are likely to secure a continuously upward trend in the price of hæmatite, and though the first call for it will surely remain with the nation which wields the trident of sea supremacy, a time is coming when hæmatite obtained from scattered ore bodies will be unable to compete against the large and cheaply worked bodies of phosphoric ores of regions more convenient to the coal.

During the last decade many of those famous ironore bodies occurring in association with limestones equivalent in age to the upper part of the English Gault, which were opened up close to Bilbao, in northern Spain, early in the 'eighties, have become exhausted, and at the pre-war rate of depletion the known ore reserves of that brought by ship to Britain, plus the weight of metal imported in the semi-manufactured state, has for twenty years past been in excess of the quantity smelted from ores wrought in British mines and quarries. Iron ore, as imported, is generally a fine, selected, high-percentage ore, but in the average of home ores the percentage of iron is compulsorily low, and the tendency is downwards, the average percentage of metallic iron contained in them having declined from 34.7 to $32 \cdot x$ in the course of the last twenty vears. In the year IgI 3 the cost of turning sixteen million tons of British ore into 5.1 million tons of pig-iron was I7.I million pounds, and the cost of turning 7.4 million tons of imported ore plus 0.6 million tons of "purple ore," plus a small amount of scrap steel turnings and mill-cinder, into 5.1 million tons of NO. 2508 , VOL. IOO] district could scarcely have lasted more than another score of years. Other valuable metasomatic hæmatite masses have been discovered further to the westward, along the Pyrenean chain, and only wait for development until better means of transport to seaboard are provided. In southern Spain the present century has seen the beginning of active development of iron mining, and in the pre-war year an output equal to more than half that from Bilbao was thence exported.

The metasomatic hæmatites of Algeria, Tunis, and Morocco follow the foothills of the Atlas range. The well-known mass at Beni Saf promises to become exhausted if worked at pre-war rate for another halfdozen years, but other high-class ore bodies have been discovered along the line of the same unconformity, 
where Mesozoic sediments rest upon the ancient schists and gneisses, and are ready for exploitation when railway facilities are provided. In Tunis the ores worked are often manganiferous, and some of them, though apparently true hæmatites, carry more than a trace of phosphorus.

Hæmatite masses formerly worked on the island of Elba and on various of the Grecian islands in the Egean Sea are either exhausted or likely to become exhausted, if quarried at the pre-war rate, within the present generation.

Produce from the Minette orefield of Lorraine has generally been converted into metal in Germany, Belgium, or France before it reached Britain, and, in consequence, the great importance of this orefield as a source of supply to British markets is often overlooked. It would appear that certainly far more than a million tons of metal brought into this country in each of several of the pre-war years might be traced back to a source of origin in the bedded Jurassic sediments of Lorraine. For the smelting of each ton of this imported metal, probably at least three tons of ore and two tons of coal (from the Hercynian belt of coalfields) must have been consumed, and it therefore appears that for quantity of mineral mined to supply the British market the area taken from France by Germany since 1870 must have held a place equả to, if not in front of, the ironfields of Spain. The iron ore wrought in Lorraine occurs as a series of beds, interstratified among Allenian (Toarcian) shales and limestones, almost identical in age with the Northamptonshire iron ores. The outcrop of the Minette formation extends from the southernmost tip of Belgium through the borders of Luxembourg with France and German Lorraine, southwards at an average distance of about three miles inside the I9I4 German border as far as Metz, and crosses into France just east of Nancy.

Of the workable orefield about 160 square miles lie on the German side of the border, fourteen square NO. 2508, VOT. IOO] miles in Luxembourg, and 208 square miles on the French side. The "Grey Bed" ores from French Lorraine are almost perfectly self-fluxing in the blastfurnace, and yield a pig-iron particularly suitable for steel-making by the basic process. According to Ger-

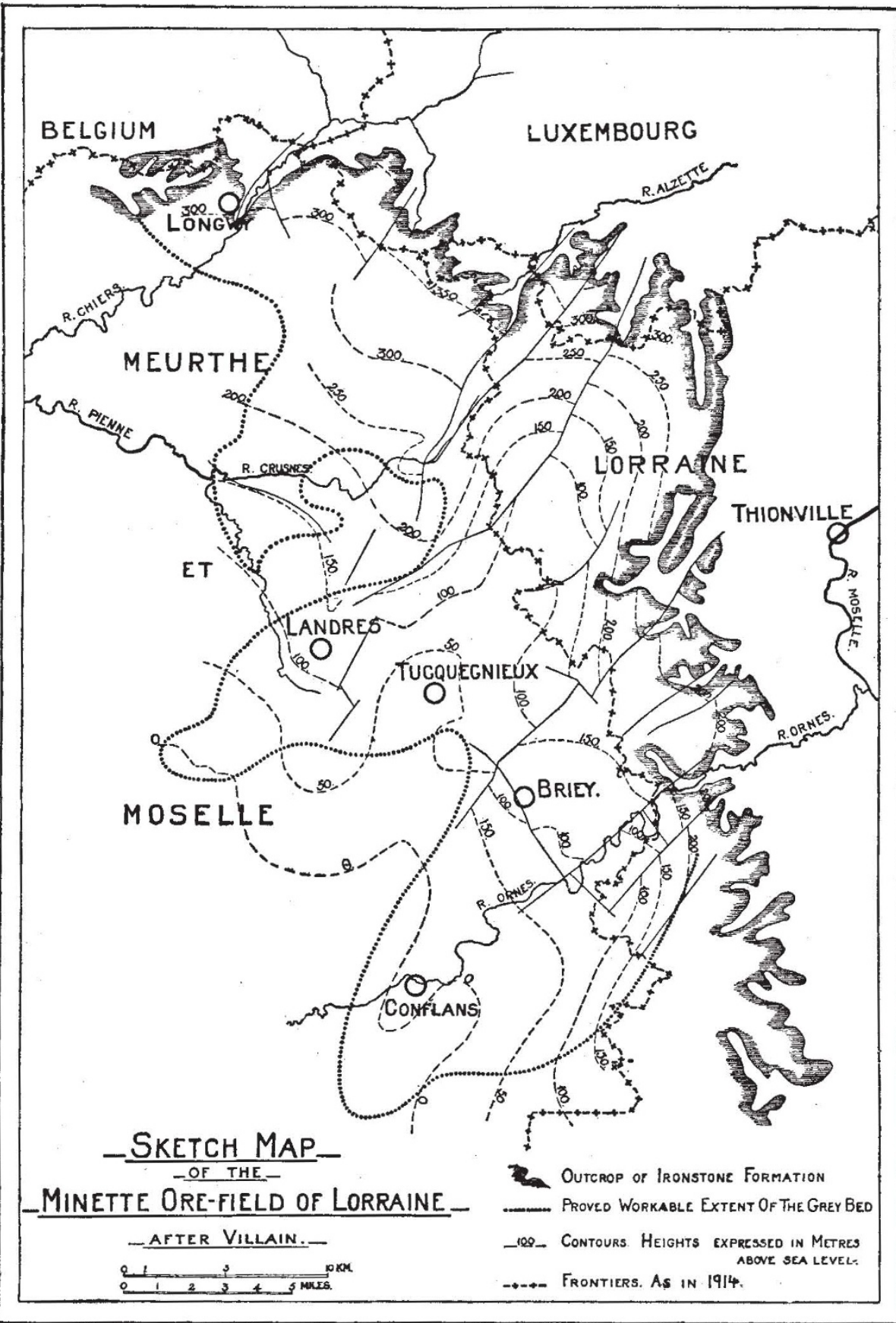

FIG. 2.

man authorities, quite the best of the ore comes from the deeper mines beneath the Briey plateau, and had not the German ironmasters been bound by agreement to continue the payment of royalties to the owners of minerals in Germain Lorraine and Luxembourg, they would have abandoned these workings in their own 
country and smelted the bulk of their pig-iron from the produce of the Briey mines. Since the late 'eighties, with the perfecting of the basic process the Lorraine district has established itself as the source of the cheapest supply of steel in Europe, and in the pre-war year the output from it was not much short of fifty million tons of ore. From German Lorraine about 300 out of 2000 million tons, and from France about 200 out of 3000 million tons proved, are won. "Truly, the Lorraine iron-ore district is an asset of the highest national importance, and there can be no doubt that, when official Germany has allowed rumours of her arrogant peace terms to be bruited, the industrialists of the Rhineland are at one with the military caste of Prussia in classing Briey and Longwy as essential strategic points.'

Despite their nearness to the ports of Britain, the orefields of western France have not received from British ironmasters the attention they deserve, and more than two-thirds of their produce was, in the pre-war years, exported to Germany. The ironstone formation there is of Upper Arenig (Llanvirnian) age, and somewhat phosphoric in character. In the Normandy district, within sixty miles of the port of Caen, an ore reserve exceeding 200 million tons has been already proved, and the output of the mines of that district is expanding rapidly. The more southerly region north of the mouth of the Loire, in Anjou and Brittany, is as yet less well developed, but there is great hope of discovery of abundant rich ores of quite similar type. Western France is dependent upon English coal for fuel, and it is argued that vessels carrying coal thither should bring return cargoes of iron ore to British blast-furnaces.

For the production of "Swedish iron" the magnetite ores of central Sweden are generally selected by hand, or, after crushing, are concentrated by the wet magnetic process and briquetted. The supply of nonphosphoric magnetite in Sweden is very limited, and the immense magnetite lenticles of Norbotten, in Lapland, are of far greater importance to the Swedish export trade. The ore mass of Kirunavaara is one of the largest in the world, and is more than five miles long. In general, this, as also the other Lapland magnetite masses, carries a good deal of fluorapatite, and being very dense requires a strong coke to carry its burden in the blast-furnace. For this reason, and because the produce from the Lapland mines requires to be converted into steel by way lof the basic process, more than four-fifths of the ore exported from Sweden has found its market in Germany and Belgium.

In Norway the ore masses associated with the ancient schists are generally of lower grade than those of Sweden, and require to be crushed, concentrated, and briquetted to make them suitable for export, and few of the mines have yet advanced to the producing stage. From Sydvaranger, near the shores of the Arctic Ocean, on the borders of Russia with Norwegian Lapland, crushed ore is being successfully concentrated and exported. Some hundred million tons of available low-grade magnetite have been proved there lying in reserve.

Previous to the war produce from the orefields of North America affected the British market rather as a commercial competitor in outside markets than as an alternative source of supoly. Since the outbreak of war, however, the British metal market, in former times Iargely supplied from the orefields of Lorraine. has had to replace its stock with steel and iron smelted in America from American ores. The "banded jasper" ironstone formations occur in the midst of Algonkian and Archrean sediments in the region of the Great Lakes, and segrefation of specular iron ore in these formations has taken place along belts determined by NO. 2508 , VOL. IOO] tectonic folding. Largest of all the ore bodies in America are those of the Mesabi range, which district is responsible for nearly two-thirds of the total U.S.A. production. For magnitude of present output, as for gross quantity of metal yielded in the past, the Lake Superior region holds precedence over all the ironfields of the world. The available reserves there are enormous, and have been variously estimated at between 2000 and 3500 million tons, with a further 7o,000 million tons of lower-grade specular material also in view. The Clinton oolitic ironstone of Silurian age in the eastern States has many features in common with the Minette series of Lorraine. It is worked extensively in the Birmingham district of Alabama, and as a producer of basic pig-iron its importance is increasing rapidly.

The ironfields of the Overseas Empire are separated from home furnaces by distances too vast for it to be economical to bring so low-priced and bulky a commodity as iron ore to compete with the produce from ironfields in the European countries which have no coal. In Canada, Australia, South Africa, New Zealand, and India, iron is already being smelted at a cost less than it can be brought in from Europe, and in due course we may expect to see local iron industries develop, perhaps to such an extent that outlying portions of the Empire may send manufactured or semi-manufactured metal to supply the British market.

Among the world's great inonfields which are supplying their raw material to the iron and steel industries only those in which the ore is to some extent phosphoric have been able since the beginning of the present century to increase their output on an extensive scale. The development of iron-mining in the various European countries and in America is shown on the diagram, Fig. 3 .

The chief natural advantages which have enabled this country to outbid foreign rivals in the overseas markets for non-phosphoric hæmatite are the native wealth of the home supply of fuel, and the accident of geography which sited our magnificent coalfields near the harbours of our coasts. The high quality and cheapness of the fuel have enabled this country to maintain the supremacy of its mercantile marine throughout the age of steam, and this has been the dominant factor in securing to our ironmasters their ample hæmatite supplies. Meanwhile, the Germans, drawing the bulk of their ore supplies from deposits in closer proximity to their coalfields, have been able at very low prices to put on the market steel which is sufficiently satisfactory made from the Minette ores of Lorraine; and in the markets of the world this product has largely supplanted the lower grades of acid steel. British ironmasters, who were the last to feel the pinch of hæmatite shortage, have foreseen little commercial advantage to be obtained by smelting the cheaper low-grade supplies of home phosphoric ores, and have been reluctant either to reorganise or to extend their works in order to compete for low-grade trade, and only for high-quality tool and special alloy steels has the British Empire continued to supply her former proportion of the world's demands. Beaten in competition for the nonphosphoric hæmatite supplies, only available from overseas, Germany perfected the basic method of steel refining, and has certainly made the best of the mineral supplies she had at hand. America also has recognised that it is cheaper to work up ores which are abundant and occur in large masses in the neighbourhood of existino transport routes, and most of her recent steel works extensions have adopted the basic open-hearth process of steel-making. It has paid both Germany and America to adopt the basic process to provide a bulk supply of steel, and it should be equally 
profitable for this country to develop a part of its steel-making practice along similar lines, and from home Jurassic ores to produce at least sufficient metal to take the place of the two or more million tons of semi-manufactured metal which until lately was imported from abroad. Probably in peace-time scarcely more than one-fifth of the total output of British pigiron is applied to purposes which suitably refined basic iron could not serve. "Does it not, therefore, seem that when labour again becomes available for the mining or quarrying of home ores, and for handling the relatively greater bulk as it passes through the furnaces, it will be sound policy here to adopt the basic process on such a scale that, even with expanding trade, it will become unnecessary to purchase from

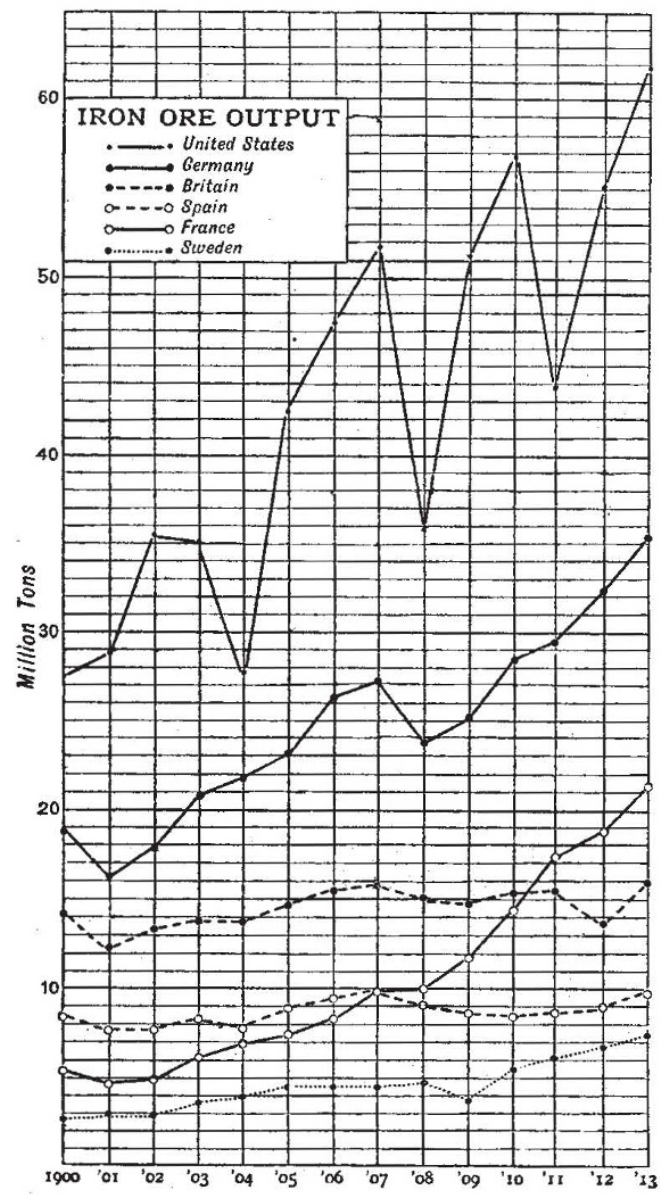

FIG. 3.- Curve of iron-ore uutput of the United States and Europe.

abroad so large a quantity of ore, for the carriage of which so great a proportion of our mercantile shipping tonnage has in the past been employed?"

Because of the short sea passage, the blast-furnaces near the western coalfields are likely to continue to bring ore from Spanish or Mediterranean ports, and to manufacture hæmatite pig-iron therefrom. To the Cleveland and East IIidland districts the orefields of western France and Scandinavia are more convenient, and there are immense possibilities for the extension of the basic iron industry for the smelting of home Jurassic ores. This latter development has already well begun, and in Yorkshire, Lincolnshire, Derbyshire, and Nottinghamshire is proceeding rapidly.

"With five thousand million tons of ore ready for NO. 2508 , VOL. IOO] quarrying or mining within fifty miles of a region which holds at least fifty thousand million tons of the very best non-anthracitic coal, there is no valid reason for the iron and steel industries of eastern England to look forward except with confidence to the time when the price of overseas hæmatite becomes prohibitive."

\section{UNIVERSITY AND EDUCATIONAL INTELLIGENCE.}

CAMBrIdge.-The professor of anatomy has, with the consent of the Vice-Chancellor, reappointed Dr. W. L. H. Duckworth, of Jesus College, to be senior demonstrator of anatomy for five years.

A sILver medal, which will be known as the Adami medal, in honour of Prof. J. G: Adami, F.R.S., is to be awarded annually in the department of pathology in Queen's University, Belfast. The founder of the medal is Mr. J. H. Stirling, Belfast.

Is connection with the Students' Section of the Institution of Electrical Engineers an address will be delivered to-morrow, November 23 , at 7 o'clock, at the City and Guilds (Engineering) College, South Kensington, by Sir Oliver Lodge, on "Astronomical Application of the Electrical Theory of Matter."

The Parliamentary correspondent of the Times states that the chances of the Education Bill passing into law this session have been materially improved. Mr. Fisher has in the last few days been in personal conference with important bodies representing local education authorities with reference to the administrative clauses of the Bill; it is understood that their support may be counted on for its second reading.

The Maypole Dairy Comparty has given roool. to the governors of the Southall County School to establish a leaving scholarship in connection with the school, tenable at the Royal College of Science, London, and to be known as the "Maypole Science Scholarship." The headmaster of the school, Mr. S. Pollitt, recently appealed to local manufacturers for financial aid to establish such science scholarships, and the example of the Maypole Company, whose works are at Southall, will, it is hoped, be followed by other industrial enterprises in the district, so that the school may be able to take its part in meeting the need of the immediate future for highly trained technical chemists and other experts in science.

WE learn from Science that the Board of Regents of the University of Minnesota has ratified by a unanimous vote the permanent agreement making the Mayo Foundation at Rochester the absolute property of the University, to be used perpetually for higher medical education and research. Securities totalling $330,000 l$, representing the fortunes of Drs. William J. and Charles Mayo, were turned over to the University. Expenses of the foundation will be paid by the Drs. Mayo until a fund of $400,000 l$. has accumulated. Thereafter the income from the fund will maintain it. The foundation has been affiliated with the University for two years, which was agreed upon as a trial period. Under the final agreement the headquarters of the foundation can be moved from Rochester to another point in the State after twenty-eight years.

THE report of the president of the University Col lege, Cork, for the year 1916-17 has been received. The number of students attending the college during that year was 486 , as against $4^{22}$ during $19^{1} 5^{-16}$, and 